\title{
FLUID INCLUSIONS IN ROCKS OF THE ARCHEAN HIGH-GRADE VARPAISJÄRVI-LAPINLAHTI AREA, CENTRAL FINLAND
}

\author{
MATTI POUTIAINEN
}

\begin{abstract}
POUTIAINEN, MATTI, 1992. Fluid inclusions in rocks of the Archean high-grade Varpaisjärvi-Lapinlahti area, Central Finland. Bull. Geol. Soc. Finland 64, Part $1,3-12$.

Fluid inclusions both in matrix quartz of metamorphic rocks and in quartz veins from five samples from the Archean high-grade Varpaisjärvi-Lapinlahti area were examined with microthermometric methods. Two types of fluid inclusions were observed: $\mathrm{CO}_{2}$-rich and $\mathrm{H}_{2} \mathrm{O}$-rich. Carbonic inclusions are dominant in the granulites and aqueous inclusions in the amphibolite facies terrain. Mineralogic P-T determinations for the granulite area yield $8-10 \mathrm{~kb} / 700-850^{\circ} \mathrm{C}$ for the peak of the metamorphism. Densities of early $\mathrm{CO}_{2}$-rich inclusions $(1.00-0.95 \mathrm{~g} / \mathrm{cc})$ are too low for the postulated conditions of formation for the inclusions. Instead, these early $\mathrm{CO}_{2}$-rich inclusions were trapped at relatively high P-T conditions $\left(5-6 \mathrm{~kb} / 775^{\circ} \mathrm{C}\right)$ during uplift and erosion of the granulite terrain. This agreement of fluid trapping P-T and the mineral equilibria may indicate fluid-present metamorphism during the late Archean about $2.7 \mathrm{Ga}$ ago. Late $\mathrm{CO}_{2}$-rich inclusions were trapped along the isochores of 0.95 to $0.76 \mathrm{~g} / \mathrm{cc}$ at pressures and temperatures below $5 \mathrm{~kb}$ and $750^{\circ} \mathrm{C}$. Aqueous fluids of low-salinity $(<3.0$ eq.wt. $\% \mathrm{NaCl})$ locally penetrated the rocks of the high-grade area during uplift/erosion and contributed to the retrograde hydration effects observed in the rocks.
\end{abstract}

Key words: Fluid inclusions, metamorphic rocks, microthermometry, metamorphism, Archean, Varpaisjärvi, Lapinlahti, Finland

Matti Poutiainen: Department of Geology, University of Helsinki, P.O. Box 115, SF-00171 Helsinki, Finland

\section{Introduction}

The granulite facies rocks of the Varpaisjärvi-Lapinlahti area are products of metamorphism under moderate pressure $(8-10 \mathrm{~kb})$ and high temperature $\left(700-850^{\circ} \mathrm{C}\right.$; Paavola, 1984). Lowpressure metamorphism is a common feature to Proterozoic granulite facies rocks of southern Finland. The metamorphism is also relatively young, i.e. 1.83-1.81 Ga (Vaasjoki and Sakko 1988). In the West Uusimaa Complex (Parras 1958), the peak granulite facies metamorphism took place at $3-5 \mathrm{~kb}$ and $750-820^{\circ} \mathrm{C}$ (Schreurs
1984, Schreurs and Westra 1986). Carbonic fluids are related to these peak metamorphic conditions, and the influx of which probably induced the granulite facies metamorphism of the area (Schreurs 1984). In the progressively metamorphosed Rantasalmi-Sulkava area, the granulite facies metamorphism of the metapelites occurred at 4.3 and $750^{\circ} \mathrm{C}$ (Korsman et al. 1984). Also in this area, the $\mathrm{CO}_{2}$-rich fluids are associated with granulite facies metamorphism (Poutiainen 1990). In the Turku region, the peak metamorphic conditions were reached at $4-6 \mathrm{~kb}$ and $\mathrm{c}$. $800^{\circ} \mathrm{C}$ (Hölttä 1986). Fluid-absent metamor- 
phism for the area has been suggested by Van Duin (1989).

The petrology, geochemistry and geochronology of the granulite/amphibolite facies terrain of the Varpaisjärvi-Lapinlahti area has been studied by Paavola $(1984,1986,1988)$ and Hölttä and Paavola (1988, 1989). Fluid inclusion studies have been performed to determine the nature of the fluids in the rocks during and after the late Archean $(2.7 \mathrm{Ga})$ metamorphism. The results are combined with the geothermobarometric determinations of Paavola (1984) and Hölttä and Paavola (1989).

\section{Geological setting and sample location}

The granulites of the Varpaisjärvi area, Central Finland, are part of the Archean granitoid and migmatite complex (Fig. 1). The rocks of the area have undergone polyphase deformation. The intense blocking of the bedrock in the Varpaisjärvi-Lapinlahti area (Paavola 1984, 1988) was attributed to overthrusting of the Iisalmi plate, from which the study area comprises a part, onto the eastern margin of the Archean craton with subsequent faulting and fragmenting of the overthrusted crust (Hölttä and Paavola 1988, 1989). The fracture and fault zones that bound the different blocks contain blastomylonitc quartzepidote rocks and amphibolites (Paavola 1988). The blocks of high metamorphic grade yield strong positive magnetic anomalies. The exposed rocks of different metamorphic grade in the adjoining blocks represent differences in erosion level. The complex comprises a variety of volcanic, plutonic and to a lesser extent sedimentogenic rocks (Paavola 1984), which already were sub-

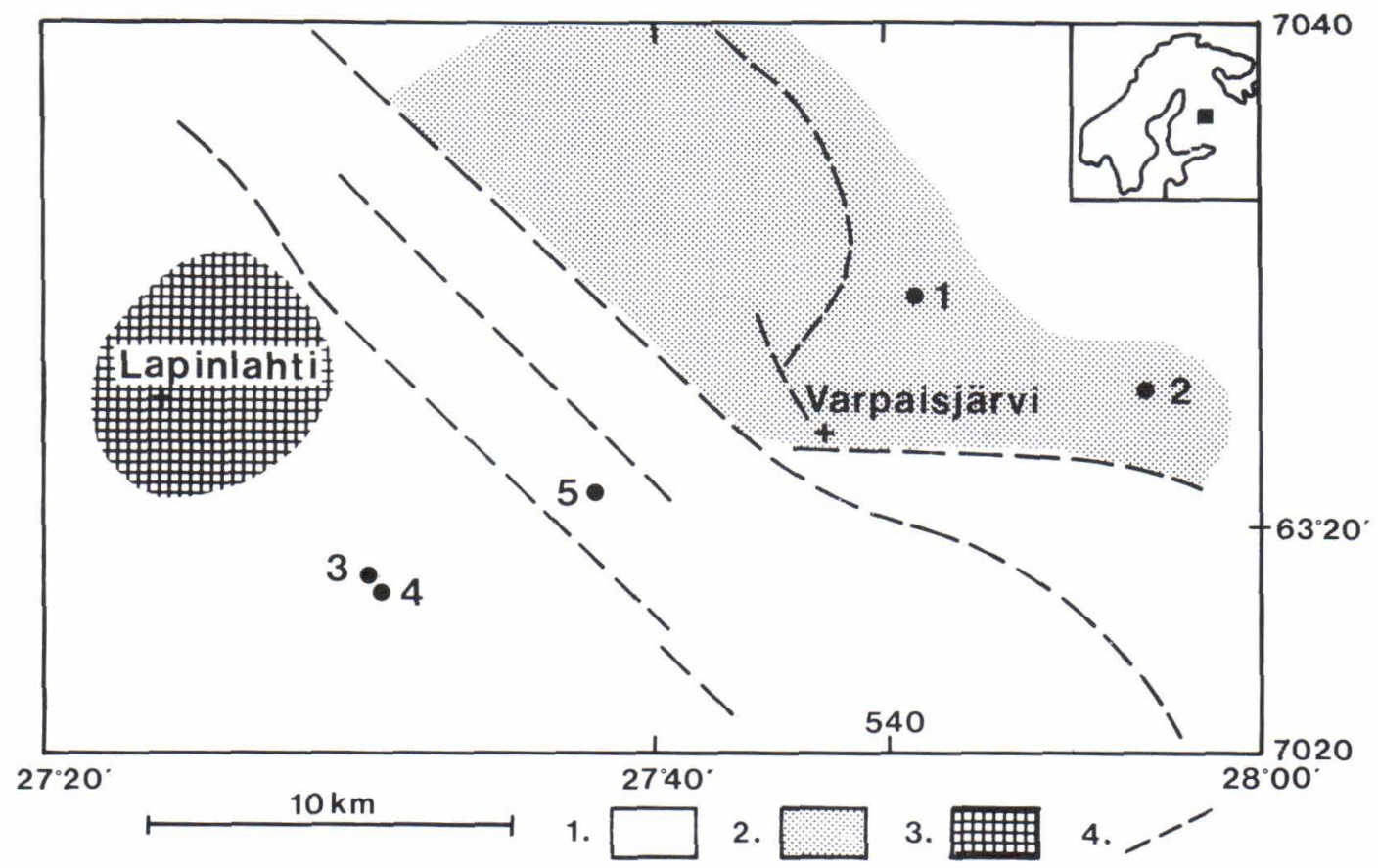

Fig. 1. A generalized geological map of the Lapinlahti-Varpaisjärvi area (modified from Paavola 1986) and the localities $(1-5)$ of the fluid inclusion samples. Symbols: 1. Archean tonalitic-trondhjemitic basement, 2. Archean high-grade metamorphic rocks, 3. Proterozoic plutonic rock, 4. Fracture or fault. 
jected to early granulite facies metamorphism possibly about $3.1 \mathrm{Ga}$ ago. This early high-grade metamorphism was probably correlated with $\mathrm{D}_{2}$ deformation (Hölttä and Paavola 1989). The subsequent metamorphism and $D_{3}$ deformation with intense neosome formation took place about

\section{$2.7 \mathrm{Ga}$ ago.}

The main part of the high-grade metamorphic area is occupied by hypersthene-bearing tonalitic-trondhjemitic granitoids (enderbites) with amphibolite enclaves and intercalations. These pyroxene amphibolites contain locally narrow intercalations of quartz-cordierite and garnetcordierite-sillimanite rocks of sedimentary origin (Paavola 1984). The rocks of the Varpaisjärvi block are cut by numerous Proterozoic diabase dikes. Geochemical characteristics of the granulite facies rocks and their lower-grade equivalents suggest that their precursors were calc-alkaline volcanic and plutonic rocks with minor sedimentogenic material.

$\mathrm{U}-\mathrm{Pb}$ zircon ages of about $3.1 \mathrm{Ga}$ from the quartz-dioritic palaeosome of the banded migmatite have been interpreted to represent either the primary crystallization of the rock or the early high-grade metamorphism. The U-Pb zircon ages of about $2.7 \mathrm{Ga}$ have been derived from the enderbites, which probably were homogenized by anatectic melting during metamorphism (Paavola 1986).

In the high-grade metamorphic block, the rocks for which fluid inclusion studies were carried out are (1) enderbitic basement with concordant U-Pb zircon and $\mathrm{K}-\mathrm{Ar}$ hornblende ages of about $2.7 \mathrm{Ga}$, and (2) quartz-cordierite rock interbedded with pyroxene amphibolites (Fig. 1). In an outcrop close to (2) a narrow horizon of kornerupine-bearing cordierite-orthoamphibole rock is exposed (Hölttä and Paavola 1989). Outside the high-grade metamorphic area, samples were taken from (3) a relatively homogeneous dioritic palaeosome of the tonalitic-trondhjemitic migmatite showing a U-Pb zircon age of about $3.1 \mathrm{Ga}$ (Paavola, 1986). The neosome material (4) consists of relatively small and evengrained granite, which contains amphibolitic relics. Samples also were collected from (5) intensively foliated biotite-rich host rock and from concordant bluish quartz veins near the NW-SE trending fracture and fault zone.

\section{Fluid inclusion types and their regional distribution}

The majority of the fluid inclusions in the enderbites of the high-grade metamorphic block are carbonic, distributed in intragranular trails, small clusters or single inclusions within quartz crystals. The relative chronology of the $\mathrm{CO}_{2}$ inclusions is deduced from their mode of occurrence (see Touret and Dietvorst, 1983). Both early and late $\mathrm{CO}_{2}$ inclusions are monophase (liquid) at room temperature $\left(+24^{\circ} \mathrm{C}\right)$ and range $<5$ to 10 $\mu \mathrm{m}$ in the longest dimension. The inclusions tend to have a negative crystal shape, especially those in small groups and single inclusions. Single and isolated groups of $\mathrm{CO}_{2}$ inclusions are subordinate in the samples. Aqueous inclusions show more irregular shapes. They are less than $10 \mu \mathrm{m}$ in size. Most $\mathrm{H}_{2} \mathrm{O}$ inclusions occur along healed microfractures, which clearly postdate the early $\mathrm{CO}_{2}$ inclusion groups. The number of $\mathrm{CO}_{2}$ and $\mathrm{H}_{2} \mathrm{O}$ inclusions encountered in the enderbites is very low. Fluid inclusions are most abundant in the samples collected from the fracture and fault zone. Some $\mathrm{H}_{2} \mathrm{O}$ inclusions in the quartz vein sample from this zone, contain a small cube of $\mathrm{NaCl}$. Mixed $\mathrm{H}_{2} \mathrm{O}-\mathrm{CO}_{2}$ inclusions have not been observed in any of the studied samples.

Regional distribution of fluid inclusion types demonstrate that the rocks of the amphibolite facies terrain (Lapinlahti) contain only $\mathrm{H}_{2} \mathrm{O}$ whereas the granulite facies terrain (Varpaisjärvi) contain almost exclusively $\mathrm{CO}_{2}$ (Fig. 2). In a transitional zone, both fluid types are almost equally present in the quartz veins (5a) and in the host rock (5b). This relatively narrow zone is restricted to the fracture and fault zones on both sides. The observed fluid distribution is very simi- 
lar to that described by Hörmann et al. (1980) from granulites and their lower-grade (amphibolite facies) marginal zone in Finnish Lapland.

\section{Microthermometric results}

Microthermometric determinations was carried out on a Fluid Inc. heating/freezing stage cooled by liquid nitrogen (see Shepherd et al. 1985). The stage was calibrated using a set of synthetic fluid inclusion standards (see Sterner and Bodnar, 1984). All temperatures reported below $+30^{\circ} \mathrm{C}$ have an estimated uncertaintity of $0.2^{\circ} \mathrm{C}$ and above this temperature the maximum error is probably $3.0^{\circ} \mathrm{C}$.

The final melting temperatures of $\mathrm{CO}_{2}$ $\left(\mathrm{T}_{\mathrm{m}} \mathrm{CO}_{2}\right)$ of early and late carbonic inclusions are measured between -55.4 and $-56.6^{\circ} \mathrm{C}$ (Table $1)$, close to the triple point of pure $\mathrm{CO}_{2}$
Table 1. Density of early and late $\mathrm{CO}_{2}$ inclusions and their melting temperatures $\left(\mathrm{T}_{\mathrm{m}} \mathrm{CO}_{2}\right)$ in the granulite facies terrain (Gra) and in the transitional zone (Tra). Sample numbers $1-2$ refer to enderbite and quartz-cordierite rock and numbers 5a and $5 \mathrm{~b}$ to quartz vein and host rock, respectively.

\begin{tabular}{|c|c|c|c|}
\hline Early $\mathrm{CO}_{2}$ & Gra/Tra & $\operatorname{Im} \underline{C O}_{2}(\underline{C})$ & Density_ $\left(\mathrm{g} / \mathrm{cm}^{3}\right)$ \\
\hline $\begin{aligned} \text { Sample } 1 \\
2 \\
5 \mathrm{a} \\
5 \mathrm{~b}\end{aligned}$ & $\begin{array}{l}\text { Gra } \\
\text { Gra } \\
\text { Tra } \\
\text { Tra }\end{array}$ & $\begin{array}{l}-56.5--56.6 \\
-56.1--56.4 \\
-56.0--56.4 \\
-56.2\end{array}$ & $\begin{array}{l}0.95 \\
1.00 \\
0.91 \\
0.93\end{array}$ \\
\hline \multicolumn{4}{|l|}{$\underline{\text { Late } \mathrm{CO}_{2}}$} \\
\hline $\begin{array}{r}\text { Sample } 1 \\
2 \\
5 a \\
5 b\end{array}$ & $\begin{array}{l}\text { Gra } \\
\text { Gra } \\
\text { Tra } \\
\text { Tra }\end{array}$ & $\begin{array}{l}-55.4 \\
-56.1--56.4 \\
-56.0--56.4 \\
-55.6--55.8\end{array}$ & $\begin{array}{l}0.91-0.86 \\
0.95-0.92 \\
0.85-0.81 \\
0.87-0.76\end{array}$ \\
\hline
\end{tabular}

$\left(-56.6^{\circ} \mathrm{C}\right)$. Thus, the $\mathrm{CO}_{2}$ seems to be pure. However, without Raman analysis the presence of small amounts $(<3 \%)$ of additional components such as $\mathrm{CH}_{4}$ and/or $\mathrm{N}_{2}$ cannot be ruled out (Touret 1981, Kerkhof 1988).

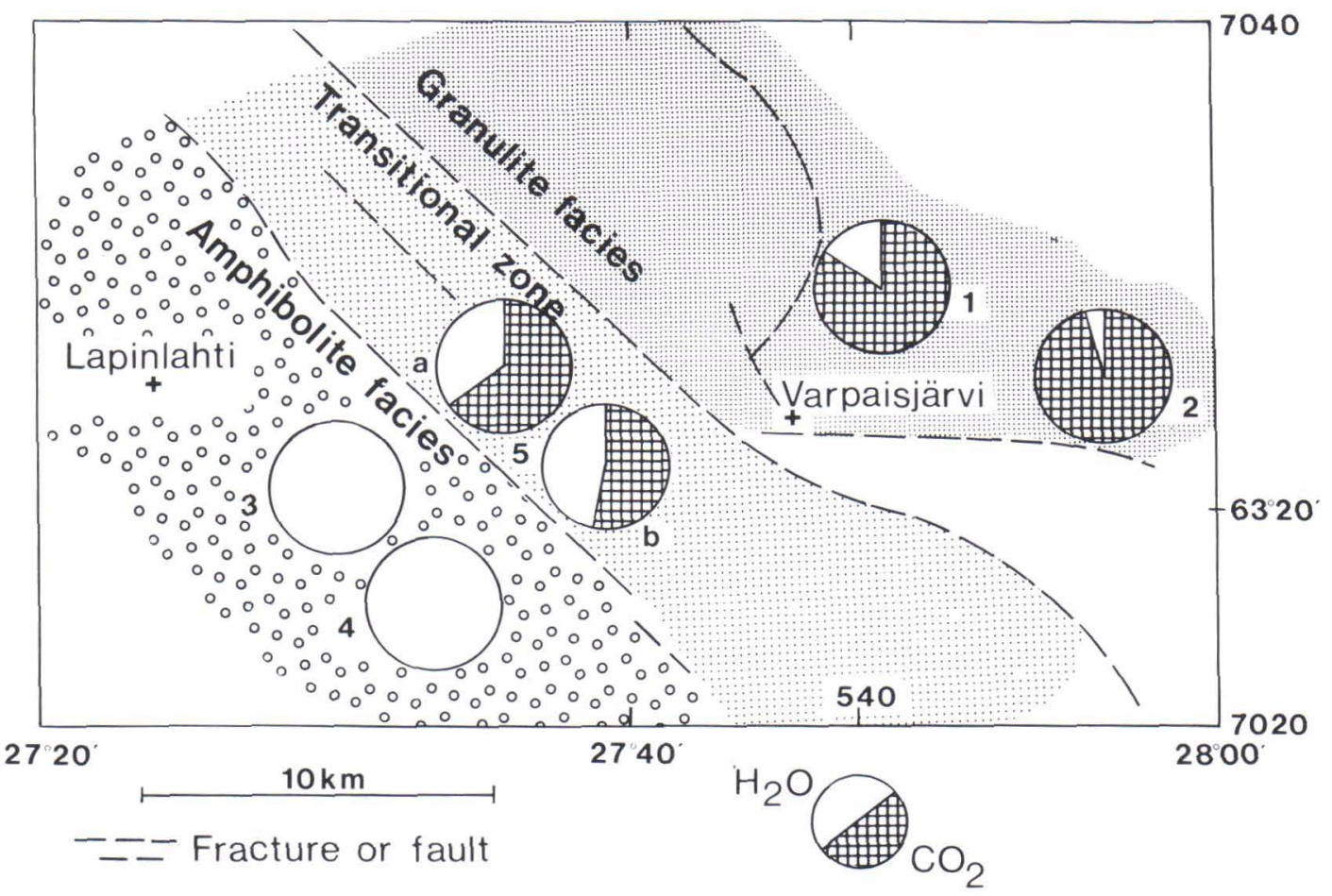

Fig. 2. Regional distribution of $\mathrm{CO}_{2}$ and $\mathrm{H}_{2} \mathrm{O}$ inclusions and their relative abundance. 


$$
\mathrm{T}_{\mathrm{h}} \mathrm{CO}_{2}\left({ }^{\circ} \mathrm{C}\right)
$$

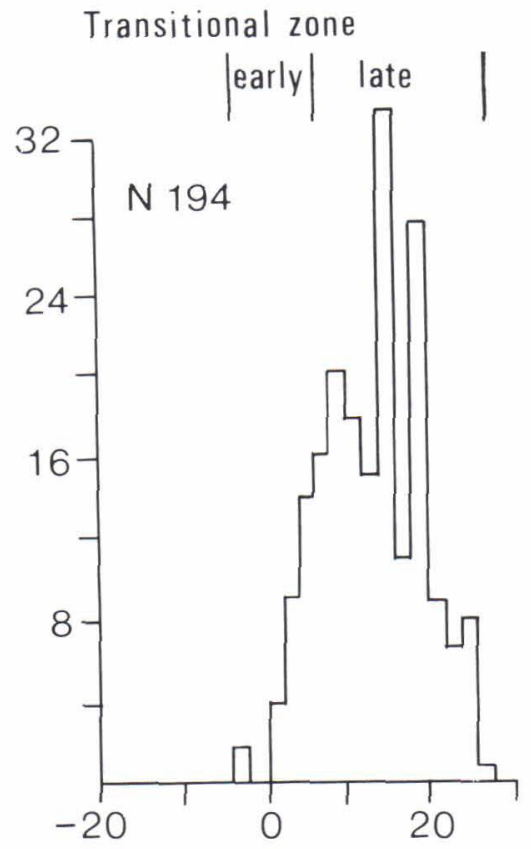

Granulite facies

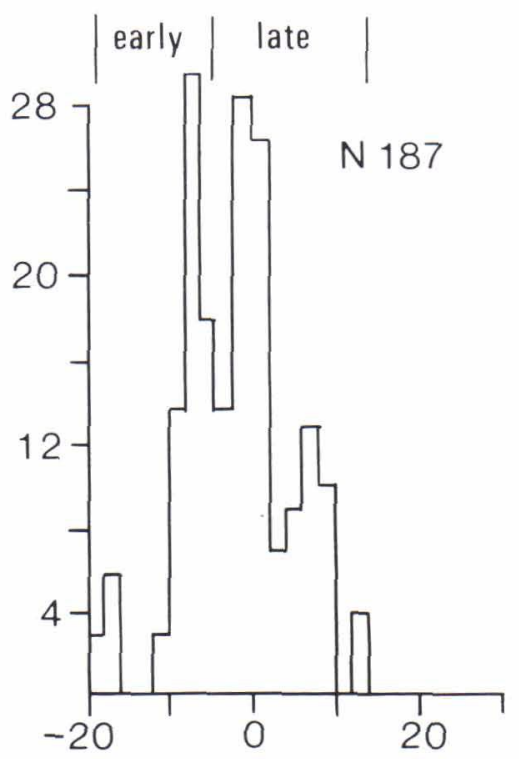

Fig. 3. Frequency histograms of $\mathrm{CO}_{2}$ homogenization temperatures $\left(\mathrm{T}_{\mathrm{h}} \mathrm{CO}_{2}\right)$ to liquid in the transitional zone and in the granulite facies terrain. Distribution of $\mathrm{T}_{h} \mathrm{CO}_{2}$ of early and late inclusions are marked with black bars. $\mathrm{N}=$ number of inclusions measured.
Histograms of homogenization temperatures of early and late $\mathrm{CO}_{2}$ inclusions $\left(\mathrm{T}_{\mathrm{h}} \mathrm{CO}_{2}\right)$ in the studied samples are shown in Fig. 3. Homogenization of $\mathrm{CO}_{2}$ inclusions takes place invariably into the liquid state. $\mathrm{T}_{\mathrm{h}} \mathrm{CO}_{2}$ varies from -20 to $+28^{\circ} \mathrm{C}$ and exhibits three or four well-defined peaks in the histograms. These $\mathrm{T}_{h} \mathrm{CO}_{2}$ values correspond to $\mathrm{CO}_{2}$ densities between about 1.00 and $0.76 \mathrm{~g} / \mathrm{cc}$. Both early and late $\mathrm{CO}_{2}$ inclusions in the high-grade metamorphic block have higher fluid densities than $\mathrm{CO}_{2}$ inclusions in the transitional zone (Table 1).

Aqueous inclusions are very rare in the samples from the high-grade metamorphic block. Their salinity is low ( $<3$ eq.wt. $\% \mathrm{NaCl}$; Potter et al., 1978)) and they exhibit both liquid and gaseous homogenization at lower $\left(180-321^{\circ} \mathrm{C}\right)$ and at higher $\left(>340^{\circ} \mathrm{C}\right)$ temperatures, respectively.

In the amphibolite facies rocks, $\mathrm{H}_{2} \mathrm{O}$ inclusions are most abundant. Their salinity varies from about 2 to 20 eq.wt. $\% \mathrm{NaCl}$ and $\mathrm{T}_{h} \mathrm{H}_{2} \mathrm{O}$ from about 100 to $300^{\circ} \mathrm{C} . \mathrm{T}_{\mathrm{h}} \mathrm{H}_{2} \mathrm{O}$ of the inclusions shows well-defined peaks at $140-170$ and $170-200^{\circ} \mathrm{C}$ for the inclusions in the host rock and quartz vein, respectively. These inclusions homogenize invariably into the liquid state. In the quartz vein many aqueous inclusions have $\mathrm{T}_{\mathrm{m}} \mathrm{H}_{2} \mathrm{O}$ below the eutectic point $\left(-20.8^{\circ} \mathrm{C}\right)$ of pure $\mathrm{H}_{2} \mathrm{O}-\mathrm{NaCl}$ system (Fig. 4). This melting point depression may be due to either metastability in the pure $\mathrm{H}_{2} \mathrm{O}-\mathrm{NaCl}$ system or more likely due to presence of some other constituents such as Ca, Mg and K (see Roedder 1984, Vanko et al. 1988). The vein quartz also contains younger NaCl-saturated aqueous inclusions. Their salinity $(30-32 \mathrm{wt} . \% \mathrm{NaCl})$ were derived from dissolution temperatures $\left(185-210^{\circ} \mathrm{C}\right)$ of $\mathrm{NaCl}$ cubes based on the asumption of pure $\mathrm{NaCl}-$ $\mathrm{H}_{2} \mathrm{O}$ (Sourirajan and Kennedy 1962). However, the actual salinity of the liquid phase in these $\mathrm{NaCl}$-saturated inclusions may be considerably lower than 30-32 wt. \% NaCl if divalent cations (Ca, Mg, K etc.) are present (see Crawford 1981, 


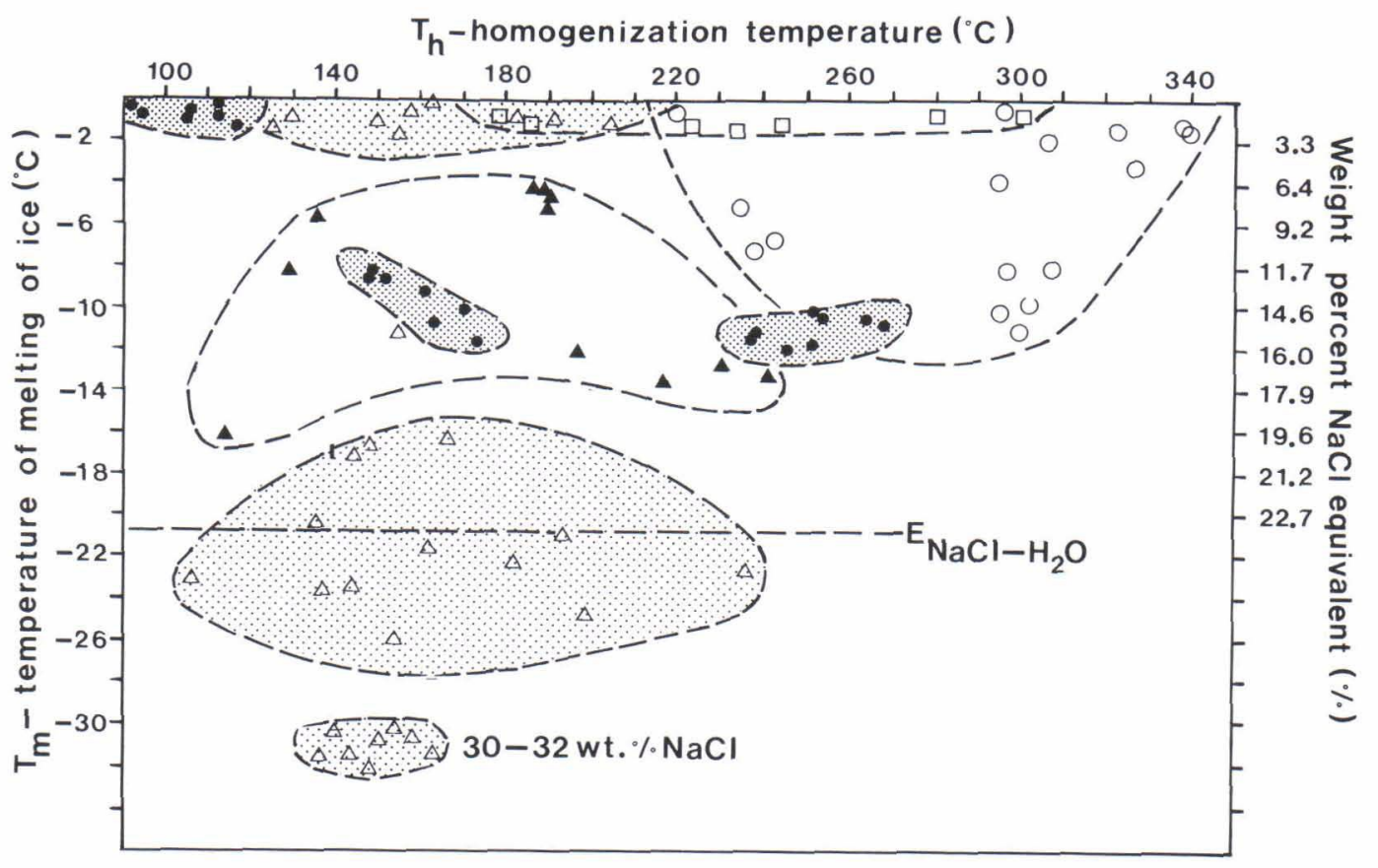

O Tonalitic-trondhjemitic basement

- Leucogranitic neosome

- Basement (transitional zone)

$\triangle$ Quartz vein ( - " - )

Enderbite ( granulite )

E Eutectic temperature $\left(-20.8^{\circ} \mathrm{C}\right)$

Fig. 4. Temperatures of homogenization versus salinity for aqueous inclusions.

Roedder 1984). $\mathrm{T}_{\mathrm{h}} \mathrm{H}_{2} \mathrm{O}$ of the inclusions ranges from 140 to $160^{\circ} \mathrm{C}$.

In the amphibolite facies Lapinlahti terrain the matrix quartz of the tonalitic-trondjhemitic basement contains $\mathrm{H}_{2} \mathrm{O}$ inclusions of intermediate salinity $(<2-15$ eq.wt. $\% \mathrm{NaCl})$. These inclusions show both liquid and gaseous homogenization at lower $\left(220-300^{\circ} \mathrm{C}\right)$ and higher $\left(>370^{\circ} \mathrm{C}\right.$ ) temperatures, respectively. Leucogranitic neosome in the lower-grade basement is clearly intrusive in nature. The granite contains aqueous inclusions, whose salinity is generally below 16 eq.wt. $\% \mathrm{NaCl}$. Three distinct populations of $\mathrm{H}_{2} \mathrm{O}$ inclusions can be distinguished, namely at $90-120,150-170$ and $230-270^{\circ} \mathrm{C}$.

\section{Discussion}

Single and small groups of carbonic inclusions with a well-defined $\mathrm{T}_{h}$ contain early $\mathrm{CO}_{2}$-rich fluid. These inclusions have the highest fluid densities $(0.95-1.00 \mathrm{~g} / \mathrm{cc})$. However, their isochores do not cross the inferred P-T box of the peak metamorphism (Fig. 5) determined by Paavola (1984) from mineral parageneses and from the $\mathrm{Fe}-\mathrm{Mg}$ distribution of certain coexisting mineral pairs of the rocks. Carbonic inclusions in intraor intergranular trails are interpreted as late $\mathrm{CO}_{2}$ inclusions, whose densities (0.86-0.95 $\mathrm{g} / \mathrm{cc}$ ) are even lower than the densities of early $\mathrm{CO}_{2}$ inclusions. The most dense $(1.00 \mathrm{~g} / \mathrm{cc}) \mathrm{CO}_{2}$ 


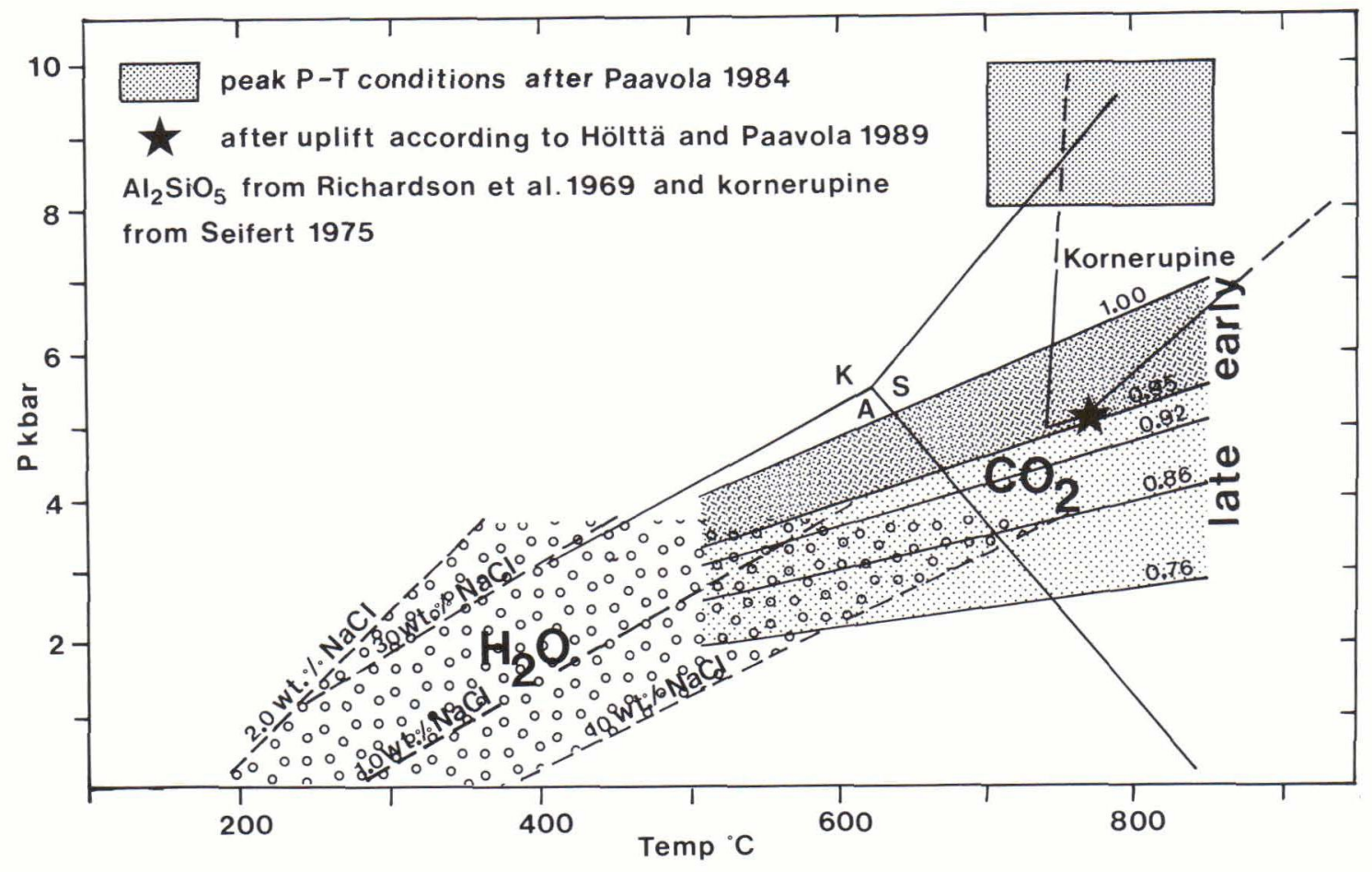

Fig. 5. Isochores of early and late $\mathrm{CO}_{2}$ inclusions (after Touret and Bottinga 1979) together with isochores of $\mathrm{H}_{2} \mathrm{O}$ inclusions (after Roedder and Bodnar 1980, Potter and Brown 1977) and their relation with pressure-temperature estimates based on mineral geothermometry and geobarometry. See text for further explanation.

inclusions were found in the quartz-cordierite rock near the exposure of the kornerupine-bearing orthoamphibole rock. The homogeneous enderbite contains somewhat lower density $(0.95$ $\mathrm{g} / \mathrm{cc}$ ) early $\mathrm{CO}_{2}$ inclusions. The isochores for the inclusions in the enderbite and quartzcordierite rock indicate pressures of about 5 to $6 \mathrm{~kb}$ at $775^{\circ} \mathrm{C}$, respectively (Fig. 5). The temperature estimate of $775^{\circ} \mathrm{C}$ is based on the geothermometric determination by Hölttä and Paavola (1989), who used the compositions of garnet and orthopyroxene (see Harley, 1984) produced in the reaction opx + sil + qtz $=$ grt + crd. These minerals occur in a rock associated with the kornerupine-bearing orthoamphibole rock. The pressure estimate of c. $5 \mathrm{~kb}$ by Hölttä and Paavola (op. cit.) is derived from the reaction opx + sil $+\mathrm{qtz}=$ crd using the geobarometer of Harris and Holland (1984). The agreement in P-T estimates for inclusion and solid state data suggest entrapment of the early $\mathrm{CO}_{2}$ inclusions after the peak of metamorphism.

Reduced $\mathrm{H}_{2} \mathrm{O}$ activities $\left(\mathrm{XH}_{2} \mathrm{O}<0.5\right)$ are commonly inferred from mineral assemblages in granulites (Hansen et al. 1984, Newton 1986). Hörmann et al. (1980) reported a change in $\mathrm{XH}_{2} \mathrm{O}$ from 0.32 to 0.10 over the amphibolite/granulite facies transition in northern Finland. In the Varpaisjärvi area low $\mathrm{H}_{2} \mathrm{O}$ activity could be supported by the fluid inclusion compositions. Various mechanisms for the explanation of low $\mathrm{H}_{2} \mathrm{O}$ activities at the peak metamorphism in granulites have been proposed by Newton (1986) and Morrison and Valley (1988).

In the Varpaisjärvi granulite area, the rocks have undergone at least an early high-grade and 
a second low-pressure metamorphic episode. The early high-grade metamorphism could have effectively dried out the host rock and if the later partial melting proceeded under fluid-absent conditions, then the observed fluid inclusions in the high-grade rocks must have formed later. The high $\mathrm{K}$-Ar hornblende $(2.7 \mathrm{Ga})$ and $\mathrm{K}$-Ar biotite $(2.4 \mathrm{Ga})$ ages derived from enderbites are attributed to »dry environment protection» by Paavola (1986). The carbon isotope compositions of calcites $\left(\delta^{13} \mathrm{C}\right)$ ranges from -3.3 to -4.4 inside and outside the granulite terrain, respectively, indicating a juvenile origin for the $\mathrm{CO}_{2}$ (Karhu1988, as quoted in Hölttä and Paavola 1988).

The enderbite, which can be considered as a neosome in relation to amphibolitic high-grade basement, contains both $\mathrm{H}_{2} \mathrm{O}$-rich and $\mathrm{CO}_{2}$-rich inclusions (Fig. 2). It is suggested that $\mathrm{H}_{2} \mathrm{O}$ partitioned preferentially into the silicate melt while $\mathrm{CO}_{2}$ remained as a residual fluid and the $\mathrm{H}_{2} \mathrm{O}$ dissolved in the melt was later released on crystallization. This may explain the hydrothermal activity and associated retrograde alterations observed in the high-grade metamorphic rocks. Thus, these inclusions may have formed during migmatization episode about $2.7 \mathrm{Ga}$ ago. Formation of hydrous mineral phases may have caused extraction of $\mathrm{H}_{2} \mathrm{O}$ from the fluid phase and the enrichment of $\mathrm{CO}_{2}$ to the remaining fluid phase (Van Reenen and Hollister 1988).

Late $\mathrm{CO}_{2}$ inclusions pose further constraints on the cooling history of the region. The set of isochores for these inclusions $(0.76-0.95 \mathrm{~g} / \mathrm{cc})$ indicate that the late influx of $\mathrm{CO}_{2}$ after the low-pressure metamorphism (i.e. $5 \mathrm{~kb} / 775^{\circ} \mathrm{C}$ ) occurred below $5 \mathrm{~kb}$. The lowest density $(0.76-0.86$ $\mathrm{g} / \mathrm{cc}$ ) fluids may have formed well below $775^{\circ} \mathrm{C}$. This indicates that the uplift/erosion path of the high-grade metamorphic block was followed by decrease in pressure and also in temperature. If the cooling would have taken place isobarically, the late $\mathrm{CO}_{2}$ inclusions are expected to have higher densities than the early $\mathrm{CO}_{2}$ inclusions. The influx of late $\mathrm{CO}_{2}$ is possibly associated with fracturing and faulting of the crust accompanied by low-temperature metasomatism (epidotization) during the early Proterozoic time $(1.93-1.90 \mathrm{Ga})$.

In the fracture and fault zone, where the Archean structures have been destroyed by mylonitization and younger deformation (Paavola 1988), the densities of late $\mathrm{CO}_{2}$ inclusions vary from 0.76 to $0.87 \mathrm{~g} / \mathrm{cc}$. This indicate that their pressure of entrapment must have been lower than $3 \mathrm{~kb}$ at temperatures below $600^{\circ} \mathrm{C}$ (Fig. 5). The high fluid inclusion content of the samples indicates that the post-metamorphic fluids have channelized to quartz veins and to the zones of weakness.

Aqueous inclusions in the transitional zone have the same range of $\mathrm{T}_{\mathrm{h}} \mathrm{H}_{2} \mathrm{O}$ values. This indicates simultaneous trapping of inclusions of varying composition in the quartz veins and in the host rock matrix.

Leucogranitic neosome material in the amphibolite facies tonalitic-trondhjemitic basement contains three different groups of inclusions. The trend of decreasing $T_{h}$ and salinity of the inclusions in the Fig. 4 is possibly explained by mixing of more saline fluid with cooler and less saline fluids during cooling of the rock. These aqueous inclusions may represent synmigmatitic fluids.

\section{Conclusions}

Early carbonic and aqueous inclusions in the Varpaisjärvi high-grade metamorphic block can not be related to early granulite facies metamorphism, which possibly took place about $3.1 \mathrm{Ga}$ ago. The infiltration of carbonic fluids occurred during uplift from granulite facies conditions $\left(8-10 \mathrm{~kb} / 700-850^{\circ} \mathrm{C}\right)$ to lower pressure conditions (c. $5 \mathrm{~kb} / 775^{\circ} \mathrm{C}$ ), which at an early stage happened nearly isothermally, maintaining a high temperature. The early $\mathrm{CO}_{2}$ inclusions were trapped during this second low-pressure metamorphic event $\left(5-6 \mathrm{~kb} / 775^{\circ} \mathrm{C}\right)$ about $2.7 \mathrm{Ga}$ 
ago. The data indicate that this second metamorphic episode may be caused by the influx of hot carbonic fluids from a deep-seated origin.

Late carbonic fluids were introduced after the second metamorphic event. This has happened at pressures below $5 \mathrm{~kb}$. In the fracture and fault zone, the infiltration of late carbonic fluids must have occurred below $3 \mathrm{~kb}$. During cooling and uplift of the high-grade metamorphic terrain, these carbonic and aqueous fluids were respon-

\section{References}

Crawford, M.L., 1981. Phase equilibria in aqueous inclusions. Mineralogical Association of Canada Short Course Handbook, 6, pp. 75-100.

Hansen, E.C., Newton, R.C \& Janardhan, A.S., 1984. Fluid inclusions in rocks from the amphibolite facies gneiss to charnockite progression in southern Karnataka, India: Direct evidence concerning the fluids of granulite metamorphism. Journal of Met. Geology 2, pp. 249-264.

Harley, S.L., 1984. An experimental study of the partitioning of $\mathrm{Fe}$ and $\mathrm{Mg}$ between garnet and orthopyroxene. Contributions to Mineralogy and Petrology 86, pp. $359-373$.

Harris, N.W.B. \& Holland, T.J.B., 1984. The significance of cordierite-hypersthene assemblages from Beitbridge region of the central Limpopo belt: evidence for rapid decompression in the Archean. American Mineralogist 69, pp. $362-367$.

Holttâ, P., 1986. Observations on the metamorphic reactions and PT conditions in the Turku granulite area. Geological Survey of Finland Bulletin 339, pp. 43-58.

Hölttä, P. \& Paavola, J., 1988. The Varpaisjärvi-Iisalmi area. Geological Survey of Finland, Guide 21, pp. 33-36.

Hölttä, P. \& Paavola, J., 1989. Kornerupine-bearing granulites and evidence of uplift in the Archean Varpaisjärvi area, Central Finland. Geological Survey of Finland Special Paper 10, pp. 11-17.

Hörmann, P.K., Raith, M., Raase, P., Ackermand, D. \& Seifert, F., 1980. The granulite complex of Finnish Lapland: Petrology and metamorphic conditions in the Ivalojoki-Inarinjärvi area. Geological Survey of Finland Bulletin 308, 95 p.

Kerkhof van den, A.M., 1988. The system $\mathrm{CO}_{2}-\mathrm{CH}_{4}-\mathrm{N}_{2}$ in fluid inclusions: Theoretical modelling and geological applications. Free University Press, Amsterdam, 206 p.

Korsman, K., Hölttä, P., Hautala, T. \& Wasenius, P., 1984. Metamorphism as an indicator of evolution and struc- sible for the retrograde alteration and low-temperature metasomatism of the rocks.

Acknowledgements. This study was supported principally by grants from the Academy of Finland. Financial support was also provided by the Geological Survey. Professor I. Haapala of the Geological Department, Dr. K. Korsman and Mr. J. Paavola of the Geological Survey and Dr. E. Roedder of the Harvard University reviewed the preliminary draft of the paper. I would like to express my appreciation to above mentioned persons.

ture of the crust in eastern Finland. Geological Survey of Finland Bulletin 343, pp. 89-96.

Morrison, J. \& Valley, J.W., 1988. Post-granulite facies fluid infiltration in the Adirondack Mountains. Geology, 16, pp. $513-516$.

Newton, R.C., 1986. Fluids of granulite facies metamorphism. In J.W. Walther and B.J. Wood, eds., Fluid rock interactions during metamorphism. Advances in physical geochemistry 5, Springer, pp. 36-59.

Paavola, J., 1984. On the Archean high-grade metamorphic rocks in the Varpaisjärvi area, Central Finland. Geological Survey of Finland Bulletin 327, 33 p.

Paavola, J., 1986. A communication in the U-Pb and K-Ar age relations of the Archean basement in the LapinlahtiVarpaisjärvi area, Central Finland. Geological Survey of Finland Bulletin 339, pp. 7-15.

Paavola, J., 1988. The Archean bedrock of the LapinlahtiVarpaisjärvi area, Central Finland. Geological Survey of Finland Special Paper 4, pp. 161-169.

Parras, K., 1958. On the charnockites in the light of a highly metamorphic rock complex in SW Finland. Bulletin de la Commission géologique de Finlande, $181 \mathrm{p}$.

Potter, R.W. \& Brown, D.L., 1977. The volumetric properties of aqueous sodium chloride solutions from 0 to $500^{\circ} \mathrm{C}$ and pressures up to 2000 bars based on regression of available data in the literature. U.S. Geological Survey Bulletin 1421-C, $36 \mathrm{p}$.

Potter, R.W., Clynne, M.A. \& Brown, D.L., 1978. Freezing point depression of aqueous sodium chloride solutions. Economic Geology 73, pp. 284-285.

Poutiainen, M., 1990. Evolution of a metamorphic fluid during progressive metamorphism in the Joroinen-Sulkava area, South-Eastern Finland, as indicated by fluid inclusions. Mineralogical Magazine 54, pp. 207-218.

Richardson, S.W., Gilbert, M.C. \& Bell, P.M., 1969. Experimental determination of kyanite-andalusite and andalusite-sillimanite equilibria: the aluminium silicate triple point. American Joural of Sciency 267, pp. 259-271. 
Roedder, E., 1984. Fluid inclusions. Reviews in Mineralogy 12, Mineralogical Society of America,

Roedder, E. \& Bodnar, R.J., 1980. Geologic pressure determinations from fluid inclusion studies. Annual Review of Earth and Planetary Science 8, pp. 263-301.

Schreurs, J., 1984. The amphibolite-granulite facies transition in West Uusimaa, SW Finland. A fluid inclusion study. Journal of metamorphic Geology 2, pp. 327-341.

Schreurs, J. \& Westra, L., 1986. The thermotectonic evolution of a Proterozoic low pressure, granulite domain, West Uusimaa, SW Finland. Contribution to Mineralogy and Petrology 93, pp. 236-250.

Seifert, F., 1975. Boron-free kornerupine: A high-pressure phase. American Journal of Science 275, pp. 57-87.

Shepherd, T., Rankin, A.H. \& Alderton, D.H.M., 1985. A practical guide to fluid inclusion studies. Blackie, $239 \mathrm{p}$.

Sourirajan, S. \& Kennedy, G.C., 1962. The system $\mathrm{H}_{2} \mathrm{O}-$ $\mathrm{NaCl}$ at elevated temperatures and pressures. American Journal of Science 260 ,pp. 115-141.

Sterner, S.M. \& Bodnar, R.J., 1984. Synthetic fluid inclusions in natural quartz. 1. types and applications to experimental geochemistry. Geochim. Cosmochim. Acta 48, pp. 2659-2668.

Touret, J., 1981. Fluid inclusions in high-grade metamorphic rocks. Mineralogical Association of Canada Short Course Handbook 6, pp. 182-208.
Touret, J. \& Bottinga, Y., 1979. Equation of state of $\mathrm{CO}_{2}$; application to carbonic inclusions. Bulletin of Mineral. 102 , pp. $577-583$.

Touret, J. \& Dietvorst, P., 1983. Fluid inclusions in highgrade anatectic metamorphites. Journal of geological Society of London 140, pp. 635-649.

Vaasjoki, M. \& Sakko, M., 1988. The evolution of the Raahe-Ladoga zone in Finland: Isotopic constraints. Geological Survey of Finland Bulletin 343, pp. 7-32.

Van Duin, J.A., 1989. The charnockitic igneous suite of the Turku region: Preliminary data. Geological Survey of Finland Special Paper 8, p. 133.

Vanko, D.A., Bodnar, R.J. \& Sterner, S.M., 1988. Synthetic fluid inclusions: VIII. Vapor-saturated halite solubility in part of the system $\mathrm{NaCl}-\mathrm{CaCl}_{2}-\mathrm{H}_{2} \mathrm{O}$, with application to fluid inclusions from oceanic hydrothermal systems. Geochim. Cosmochim. Acta 52, pp. 2451-2456.

Van Reenen, D.D. \& Hollister, L.S., 1988. Fluid inclusions in hydrated granulite facies rocks, southern marginal zone of the Limpopo Belt, South Africa. Geochim. Cosmochim. Acta 52, pp. 1057-1064.

Received October, 151991

Revision accepted December 28, 1991 